\title{
Efek Antifertilitas dari Ekstrak Daun Pepaya (Carica papaya L.) pada Tikus Putih Jantan Galur Sprague Dawley
}

\author{
Antifertility Effects of Papaya Leaf Extract (Carica papaya L.) in Male White Mouse Sprague Dawley \\ Strain
}

Penulis

Ema Dewanti ${ }^{1 *}$, Daniek Viviandhari ${ }^{1}$, Nitia Lonica ${ }^{1}$, Safitri Mutia Isnarningtyas ${ }^{1}$

Afiliasi

${ }^{1}$ Fakultas Farmasi dan Sains, Universitas Muhammadiyah Prof. DR. HAMKA, Jakarta, DKI Jakarta, 13460, Indonesia

\section{Kata Kunci \\ antifertilitas \\ $\partial$ bobot testis \\ - daun Pepaya (Carica papaya L.) \\ $\rightarrow$ kualitas spermatozoa \\ $\Rightarrow$ vesikula seminalis \\ Keywords \\ $\ni$ antifertility \\ - Papaya leaves (Carica papaya L.) \\ $\rightarrow$ sperm quality \\ $\rightarrow$ weight of testis \\ $\Rightarrow$ vesicle seminalis}

Diterima 26 Agustus 2019 Direvisi 16 Oktober 2019 Disetujui 09 April 2020

*Penulis Koresponding Ema Dewanti email: ema_dewanti@yahoo.com

\section{ABSTRAK}

Daun pepaya mengandung senyawa alkaloid, flavonoid, saponin, dan tanin yang diduga memiliki efek antifertilitas. Tujuan penelitian ini adalah untuk mengetahui efek antifertilitas dari ekstrak daun pepaya dengan parameter kualitas sperma serta bobot testis dan vesikula seminalis pada tikus putih jantan galur Sprague Dawley. Penelitian ini dibagi menjadi 2 tahap yaitu ekstraksi dan uji antifertilitas. Ekstraksi dilakukan dengan metoda maserasi bertingkat menggunakan pelarut etanol, etil asetat dan n-heksana. Perlakuan uji antifertilitas terbagi menjadi delapan kelompok yaitu 2 kelompok kontrol dan 6 kelompok perlakuan (ekstrak etanol 100 dan 150 mg/kg BB, ekstrak etil asetat 100 dan 150 mg/kg BB, ekstrak n-heksana 100 dan $150 \mathrm{mg} / \mathrm{kg} \mathrm{BB}$ ). Ekstrak daun pepaya diberikan secara oral selama 20 hari. Pada hari ke-21 tikus dibedah dan dianalisa kualitas spermatozoa serta diukur bobot testis dan vesikula seminalis. Data yang didapat diuji secara statistik dengan ANOVA satu arah dan dilanjutkan dengan uji Tukey HSD. Hasil penelitian menunjukkan ekstrak n-heksana, ekstrak etil asetat dan ekstrak etanol $70 \%$ daun pepaya dapat menurunkan jumlah dan viabilitas spermatozoa serta menurunkan bobot testis dan vesikula seminalis. Ekstrak yang paling baik dalam mempengaruhi efek antifertilitas adalah ekstrak etanol 70\% dosis $150 \mathrm{mg} / \mathrm{kgBB}$.

\section{ABSTRACT}

Papaya leaves contain alkaloid, flavonoids, saponins, and tannins which are thought to have antifertility effects. The purpose of this study was to determine the antifertility effects of papaya leaf extract with sperm quality parameters and weight of the testes and seminal vesicles in male white rats Sprague Dawley strain. This research was divided into 2 stages, extraction and antifertility test. Extraction was carried out using maceration methods using ethanol, ethyl acetate and n-hexane solvents. Antifertility test treatments were divided into eight groups, 2 control groups and 6 treatment groups (ethanol extract at 100 and $150 \mathrm{mg} / \mathrm{kg}$ b.wt., ethyl acetate extract at 100 and $150 \mathrm{mg} / \mathrm{kg}$ b.wt., $\mathrm{n}$-hexane extract at 100 and 150 $\mathrm{mg} / \mathrm{kg}$ b.wt.). Papaya leaf extract is given orally for 20 days. On day 21th the rats were dissected and analyzed for the quality of spermatozoa and measured the weight of the testicles and seminal vesicles. The data obtained were tested statistically with one-way ANOVA and continued with the Tukey HSD test. The results showed that $n$-hexane extract, ethyl acetate extract and $70 \%$ ethanol extract of papaya leaves could reduce the number and viability of spermatozoa and reduce the weight of the testes and seminal vesicles. The best extract to influence the antifertility effect is $70 \%$ ethanol extract dose $150 \mathrm{mg} / \mathrm{kg} \mathrm{b.wt}$. 


\section{PENDAHULUAN}

Indonesia adalah negara dengan urutan keempat dengan jumlah penduduk terbesar. Jumlah penduduk Indonesia di tahun 2019 diproyeksikan sebesar 267 juta jiwa (Bappenas 2019). Laju pertumbuhan penduduk yang meningkat akan menyebabkan pemerintah menghadapi kesulitan dalam menyediakan kebutuhan dasar penduduk seperti sandang, pangan, papan dan pekerjaan serta pendapatan rakyat. Tingkat pendapatan rendah akan menyebabkan bertambahnya pengangguran, kemiskinan dan keterbelakangan negara (BKKBN 2016).

Masalah kependudukan di Indonesia yaitu jumlah penduduk yang besar dan laju pertumbuhan penduduk yang relatif masih tinggi memerlukan upaya untuk mengendalikannya. Untuk menekan jumlah penduduk, pemerintah melalui BKKBN mengatasi dengan berbagai cara salah satunya adalah dengan menggalakkan Keluarga Berencana (KB). Pelayanan KB hampir semuanya ditujukan untuk wanita dan memberikan sedikit perhatian dalam penggunaan kontrasepsi bagi pria yang efektif dan konsisten serta masih adanya pertentangan dengan keyakinan agama (BKKBN 2016). Faktor penyebab kurangnya keikutsertaan pria dalam mengikuti program keluarga berencana antara lain adalah kurangnya pilihan jenis kontrasepsi pria. Metode kontrasepsi yang digunakan pria sampai saat ini adalah kondom, pantang berkala, senggama terputus dan vasektomi (Nuraini et al. 2012). Berdasarkan penelitian Sutinah (2017) tentang keikutsertaan pria dalam ber-KB di daerah Jawa Timur dapat disimpulkan bahwa responden pria beranggapan pria ber-KB adalah tabu $(17 \%)$, vasektomi dapat menyebabkan impotensi (22\%) dan $47 \%$ responden tidak pernah mengikuti sosisalisasi KB.

Spermatozoa merupakan sel gamet pria yang dihasilkan dari organ reproduksi jantan yang disebut testis. Selain memproduksi spermatozoa, testis juga memproduksi hormon testosteron. Hormon testosteron merupakan hormon androgen yang dapat mengendalikan libido dan seks pada pria. Hormon testosteron bersama dengan Lutenizing Hormone (LH) dan Folicle Stimulating Hormone (FSH) bertanggung jawab terhadap spermatogenesis, pematangan sperma, dan meningkatkan ekskresi fruktosa oleh vesikula seminalis sebagai nutrisi utama spermatozoa (Guyton \& Hall 2008). Apabila terjadi peningkatan pada spermatogenesis, maka akan disertai pula dengan peningkatan bobot dan volume testis. Apabila terjadi penurunan pada spermatogenesis maka akan disertai dengan penurunan bobot dan volume testis karena pengaruh berkurangnya sperma dari testis (Oyewopo et al. 2011).

Infertilitas ditentukan oleh kualitas spermatozoa. Kualitas meliputi beberapa aspek yaitu konsentrasi atau jumlah spermatozoa, viabilitas (daya hidup) spermatozoa, morfologi (bentuk) spermatozoa dan motilitas spermatozoa. Infertilitas dapat terjadi jika jumlah sperma dibawah normal, bentuk sperma tidak normal (memiliki kepala atau ekor yang normal) (Guyton \& Hall 2008).

Salah satu upaya yang harus dilakukan untuk mensukseskan program KB adalah mencari alternatif KB yang aman dengan menggunakan bahan alam sebagai kontrasepsi. Penggunaan bahan alam sebagai kontrasepsi banyak digunakan oleh masyarakat pedesaan mengikuti kebiasaan nenek moyang terdahulu. Disisi lain meningkatnya jumlah akseptor KB pada wanita memberikan dampak terhadap krisis logistik kontrasepsi. Terganggunya pasokan logistik dan menurunnya jangkauan pelayanan kontrasepsi di wilayah terpencil dapat berakibat meningkatnya kembali angka fertilitas. Hal yang perlu dilakukan adalah upaya untuk mengoptimalkan penelitian untuk mencari bahan-bahan kontrasepsi pria yang ideal dan alami, khususnya yang berasal dari bahan alami (Tasmaya 2000).

Salah satu bahan alam yang telah diteliti sebagai antifertilitas adalah tanaman pepaya. Pepaya (Carica papaya L.) adalah tanaman yang mudah ditemui dan mudah ditanam dalam pekarangan rumah. Ekstrak metanol biji pepaya dengan dosis $100 \mathrm{mg} / \mathrm{kg}$ BB diketahui memiliki efek antifertilitas terhadap tikus jantan. Biji pepaya dapat menurunkan motilitas spermatozoa, menghambat populasi spermatogonium dan spermatosit primer tikus jantan. Biji pepaya diketahui mengandung senyawa flavonoid, saponin dan tanin (Agustina \& Murwani 2013). Pada penelitian yang dilakukan oleh Nkeiruka et. al. (2013) ekstrak metanol daun pepaya pada dosis $200 \mathrm{mg} / \mathrm{kg}$ BB dan $400 \mathrm{mg} / \mathrm{kg}$ BB dapat menurunkan jumlah sperma dan meningkatkan jumlah sperma abnormal. Menurut Nkeiruka et. al. (2013) senyawa yang diduga berperan adalah papain, meskipun mekanisme pasti daun pepaya dalam menurunkan jumlah sperma belum sepenuhnya diketahui. Daun pepaya mengandung senyawa alkaloid, flavonoid, glikosida dan tanin (Mahatriny et al. 2014). Selain itu pada daun dan juga akar mengandung polifenol (Depkes 2000). Daun pepaya diketahui berkhasiat sebagai anti kanker, antioksidan, antidiabetes, antifertilitas, antiinflamasi, anthelmintika, antibakteri, antimalaria, dan untuk

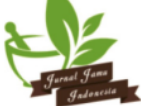


pengobatan demam berdarah (Rahayu \& Tjitraresmi 2016). Beberapa senyawa yang diduga memiliki efek antifertilitas adalah flavonoid (Prasetyaningrum et al. 2015), selain itu senyawa alkaloid, isoflavonoid, steroid, triterpen dan xanton (Adnan \& Pagarra 2000).

Berdasarkan hal tersebut diatas perlu dilakukan penelitian lebih lanjut tentang efek daun pepaya sebagai obat KB pria dengan menggunakan 3 pelarut yang berbeda kepolarannya yaitu n-heksan, etil asetat dan etanol 70\%. Ekstraksi dengan menggunakan 3 pelarut ini bertujuan untuk menarik senyawa yang berbeda tingkat kepolarannya, sehingga diketahui senyawa apa yang memiliki potensi terbaik sebagai antifertilitas. Parameter yang dilihat adalah kualitas spermatozoa, bobot testis, dan vesikula seminalis tikus putih jantan galur Sprague Dawley.

\section{METODE \\ Bahan}

Daun pepaya yang diperoleh dari BALITRO Bogor, tikus putih (Rattus norvergicus) jantan galur Sprague Dawley (SD) dengan berat badan 150-250 gram yang diperoleh dari Fakultas Peternakan Institut Peternakan Bogor, heksana, etil asetat, etanol 70\%, ketamineHameln (Combiphar, Indonesia), serbuk Mg (Merck, Germany), $\mathrm{HCL}$ pekat, $\mathrm{FeCl}_{3}$ (Merck, Germany), $\mathrm{NaCl}$, $\mathrm{Na}$ $\mathrm{CMC}$, asam asetat anhidrat, $\mathrm{H}_{2} \mathrm{SO}_{4}$ pekat, aquadest.

\section{Alat}

Maserator, vacuum rotary evaporator (Eyela, Japan), mikroskop (Novel, China), Improved nebauer haemocytometer (China), sonde, alat suntik, timbangan analitik (Ohaus, USA), alat bedah minor, pinset.

\section{Ekstraksi Daun Pepaya}

Daun pepaya yang telah dibersihkan kemudian dikeringkan dan dibuat serbuk. Serbuk daun pepaya dimaserasi bertingkat menggunakan cairan penyari yaitu $n$-heksana, etil asetat dan etanol $70 \%$. Masingmasing maserat yang diperoleh diuapkan dengan rotary evaporator hingga diperoleh ekstrak kental. Standarisasi ekstrak untuk ekstrak daun pepaya dilakukan perhitungan rendemen dan penetapan kadar air (Depkes 2008), serta penapisan fitokimia (Depkes 1995; Hanani 2014).

\section{Uji Antifertilitas}

Penelitian uji antifertilitas ini telah disetujui oleh Komisi Etik Penelitian Kesehatan UHAMKA dengan nomor 02/18.03/004. Tikus putih yang berjumlah 32 diaklimatisasi dalam ruang kandang selama 7 hari untuk mengadaptasikan hewan pada lingkungan yang baru dengan diberi minum dan pakan standar. Pada tahap ini dilakukan pengamatan terhadap keadaan umum dan penimbangan berat badan setiap hari agar diperoleh tikus yang sehat serta bobotnya sesuai dengan kriteria yang ingin dipakai.

Tikus dibagi dalam 8 kelompok perlakuan yaitu : kelompok normal (I), kelompok kontrol NaCMC (II) diberikan dengan $\mathrm{NaCMC}$ 0,5\% dan 6 kelompok perlakuan yang diinduksi dengan ekstrak daun pepaya. Kelompok perlakuan tersebut adalah kelompok perlakuan ekstrak etanol $70 \%$ daun pepaya dosis 100 $\mathrm{mg} / \mathrm{kg}$ BB (III), kelompok perlakuan ekstrak etanol $70 \%$ daun pepaya dosis $150 \mathrm{mg} / \mathrm{kg}$ BB (IV), kelompok perlakuan ekstrak etil asetat daun pepaya dosis 100 $\mathrm{mg} / \mathrm{kg} \mathrm{BB}(\mathrm{V})$, kelompok perlakuan ekstrak etil asetat daun pepaya dosis $150 \mathrm{mg} / \mathrm{kg}$ BB (VI), kelompok perlakuan ekstrak heksan daun pepaya dosis $100 \mathrm{mg} / \mathrm{kg}$ BB (VII), kelompok perlakuan ekstrak heksan daun pepaya dosis $150 \mathrm{mg} / \mathrm{kg} \mathrm{BB}$ (VIII).

Tikus diinduksi dengan sediaan uji (sesuai kelompok) 1 kali sehari secara oral selama 20 hari. Pada hari ke 21 tikus dianestesi dengan ketamin dan kemudian dilakukan pembedahan untuk menimbang bobot testis dan vesikula seminalis serta mengamati kualitas spermatozoa yaitu menghitung jumlah, viabilitas dan motilitas spermatozoa.

Bagian testis dan vesika seminalis diambil dan diletakkan diatas kaca arloji kemudian ditimbang. Berat testis dan berat vesikula seminalis dihitung dengan rumus:

$\%$ bobot testis $=\frac{\text { Bobot testis }}{\text { Berat } \text { badan }} \times 100 \%$

$\%$ bobot vesikula seminalis $=\frac{\text { Bobot vesikula seminalis }}{\text { Berat badan }} \times 100 \%$

Pengambilan spermatozoa dilakukan dengan cara bagian epididimis kiri dan kanan disayat untuk mengeluarkan spermatozoa. Kemudian bagian epidimis tersebut diletakkan dalam cawan petri yang telah berisi larutan $\mathrm{NaCl}$ fisiologis dan dipotong kecil-kecil hingga terbentuk suspensi. Suspensi semen diambil sebanyak $10 \mu \mathrm{L}$ kemudian disisipkan kedalam ruang hitung hemasitometer. Jumlah spermatozoa pada 5 kamar hitung dihitung dengan menggunakan rumus (Rudini 2016) :

Jumlah sperma $=\frac{N(A+B+C+D+E)}{2} \times 10^{6} \mathrm{sperma} / \mathrm{ml}$

Keterangan : $\mathrm{N}=$ jumlah sperma pada kotak $\mathrm{A}, \mathrm{B}, \mathrm{C}, \mathrm{D}$, dan E (Improved nebauer haemocytometer) 
Suspensi spermatozoa dipipet sebanyak 1 tetes, kemudian diletakkan pada objek glass dan ditetesi dengan pewarna Eosin 2\% setelah tercampur ditutup dengan cover glass. Preparat diamati dengan menggunakan mikroskop. Amati jumlah spermatozoa dalam 5 lapangan pandang untuk memperoleh 200 spermatozoa (Simbolon et al. 2013). Kemudian dihitung jumlah spermatozoa yang hidup dan mati. Viabilitas dihitung dengan rumus :

Viabilitas $(\%)=\frac{\text { spermatozoa hidup }}{\text { jumlah spermatozoa }} \times 100 \%$

\section{Analisa Data}

Data yang diperoleh berupa bobot testis, bobot vesikula seminalis, jumlah dan viabilitas spermatozoa dianalisa dengan uji analisis varian (ANOVA) satu arah dengan taraf signifikansi $95 \%(0,05)$ kemudian dilanjutkan dengan uji Tukey HSD untuk membandingkan perbedaan antar kelompok uji (Priyatno 2012).

\section{HASIL DAN PEMBAHASAN \\ Ekstraksi Daun Pepaya}

Daun pepaya yang diperoleh dari BALITTRO Bogor, dimaserasi secara bertingkat dengan cairan penyari heksan, etil asetat dan etanol 70\%. Filtrat dari masingmasing cairan penyari diuapkan dan didapatkan ekstrak kental. Standarisasi ekstrak untuk ekstrak daun pepaya adalah perhitungan rendemen ekstrak dan kadar air. Dari Tabel 1, terlihat ekstrak n-heksan memiliki persentase rendemen paling besar jika dibandingkan dengan ekstrak kental etanol $70 \%$ dan ekstrak etil asetat. Berdasarkan hasil penapisan fitokimia, ekstrak n-heksan diketahui mengandung senyawa alkaloid dan flavonoid, ekstrak etil asetat mengandung senyawa alkaloid, flavonoid dan saponin, sedangkan ekstrak etanol $70 \%$ mengandung senyawa alkaloid, flavonoid, saponin dan tanin. Hal ini menunjukan kandungan senyawa dalam daun pepaya yang digunakan dalam penelitian ini lebih banyak yang bersifat non polar jika dibandingkan dengan senyawa yang bersifat polar dan semi polar meskipun golongan senyawa dalam ekstrak $\mathrm{n}$-heksan memiliki jumlah yang lebih sedikit.

\section{Uji Antifertilitas}

Setelah mendapatkan perlakuan selama 20 hari sesuai dengan kelompoknya masing-masing, rata-rata persentase bobot testis dan vesika seminalis pada kelompok perlakuan mengalami penurunan jika dibandingkan dengan kelompok normal. Data selengkapnya tersaji dalam Tabel 2.

Berdasarkan analisa statistik, didapatkan data persentase penurunan bobot testis dan vesika seminalis terdistribusi normal dan homogen sehingga analisa data dilanjutkan dengan uji ANOVA satu arah dengan tujuan mengetahui apakah ada perbedaan yang bermakna pada setiap kelompok perlakuan dengan ketentuan $p<0,05$. Hasil uji data persentase bobot testis dan vesikula seminalis masing-masing

Tabel 1. Karakteristik Ekstrak Daun Pepaya

\begin{tabular}{lccc}
\hline \multicolumn{1}{c}{ Jenis } & Hasil (g) & Rendemen (\%) & Kadar Air (\%) \\
\hline Ekstrak kental $n$ heksana & 31,85 & 6,36 & 2,75 \\
Ekstrak kental etil asetat & 8,28 & 1,65 & 1,69 \\
Ekstrak kental etanol 70\% & 15,70 & 3,14 & 5,82 \\
\hline
\end{tabular}

Tabel 2. Rata-rata (\%) Bobot Testis Terhadap Berat Badan

\begin{tabular}{lcc}
\hline \multicolumn{1}{c}{ Kelompok Perlakuan } & $\begin{array}{c}\text { Persentase Bobot Testis } \\
\text { (\%) }\end{array}$ & $\begin{array}{c}\text { Persentase Vesikula Seminalis } \\
\text { (\%) }\end{array}$ \\
\hline Kelompok Normal & 1,22 & 0,76 \\
Kelompok Negatif & 1,22 & 0,74 \\
Ekstrak N-heksana $100 \mathrm{mg} / \mathrm{kgBB}$ & 1,19 & 0,67 \\
Ekstrak N-heksana $150 \mathrm{mg} / \mathrm{kgBB}$ & 1,17 & 0,62 \\
Ekstrak Etil Asetat $100 \mathrm{mg} / \mathrm{kgBB}$ & 1,13 & 0,48 \\
Ekstrak Etil Asetat $150 \mathrm{mg} / \mathrm{kgBB}$ & 1,13 & 0,48 \\
Ekstrak Etanol $100 \mathrm{mg} / \mathrm{kgBB}$ & 1,09 & 0,36 \\
Ekstrak Etanol $150 \mathrm{mg} / \mathrm{kgBB}$ & 1,05 & 0,35 \\
\hline
\end{tabular}




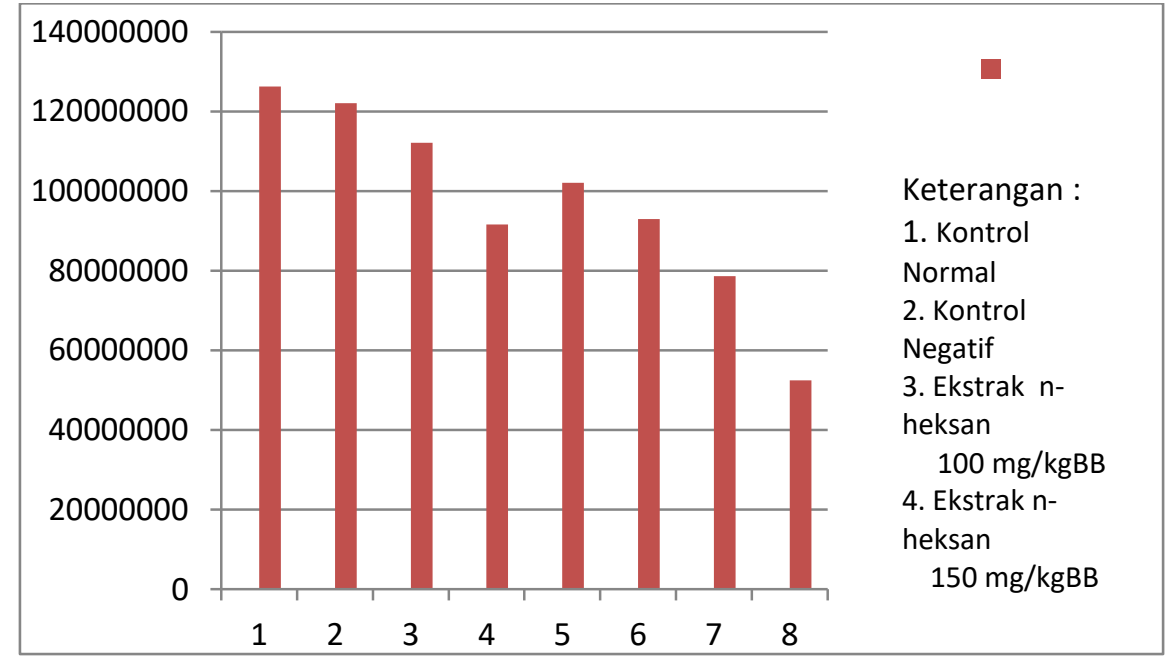

Gambar 1. Histogram Jumlah Spermatozoa

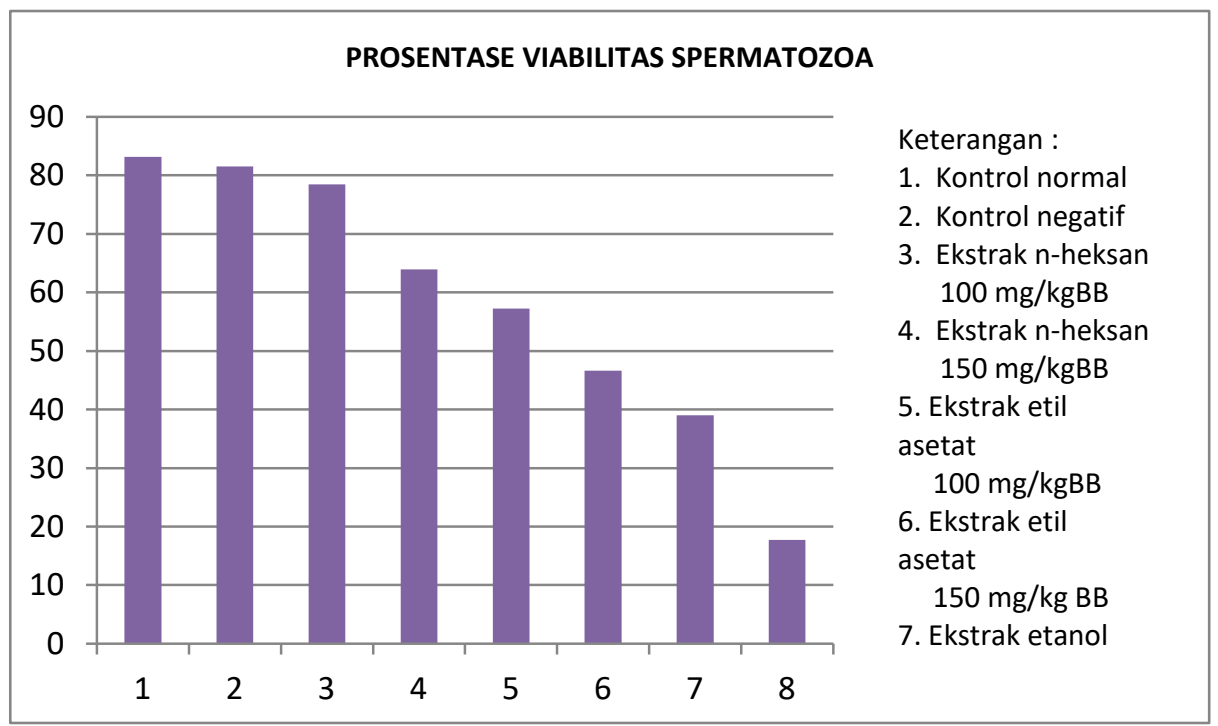

Gambar 2. Histogram Prosentase Viabilitas Spermatozoa

menunjukkan nilai $p=0,000$, maka nilai tersebut kurang dari 0,05. Analisa tersebut menunjukkan bahwa ekstrak daun pepaya memiliki pengaruh secara bermakna terhadap penurunan bobot testis dan vesikula seminalis. Uji statistika dilanjutkan dengan uji Tukey HSD dengan tujuan untuk mengetahui perbedaan antara tiap kelompok perlakuan. Pada uji Tukey HSD menunjukkan adanya perbedaan yang bermakna antara kelompok normal dengan kelompok ekstrak. Hal ini sesuai dengan fungsi testis sebagai organ genital untuk memproduksi sperma. Penurunan berat testis (atrofi) dapat mengakibatkan infertilitas. Hal ini dapat mempengaruhi proses spermatogenesis yang pada akhirnya akan mempengaruhi jumlah dan kualitas sperma (Mayasari \& Mardiroharjo 2012). Vesikula seminalis adalah bagian dari organ reproduksi pria yang berfungsi untuk menampung sperma. Semakin sedikit sperma yang ditampung dalam vesikula seminalis maka bobot vesikula seminalis akan semakin mengecil.

Jumlah spermatozoa dan prosentase viabilitas spermatozoa dari tiap kelompok dapat dilihat pada Gambar 1 dan 2. Data jumlah spermatozoa dan prosentase viabilitas spermatozoa tiap kelompok dianalisa menggunakan ANOVA 1 arah dan didapatkan nilai $p<0,05$, hal ini menunjukkan bahwa terdapat perbedaan yang bermakna antar perlakuan. Selanjutnya dilakukan uji Tukey HSD dengan tujuan untuk mengetahui perbedaan antar tiap kelompok perlakuan. Berdasarkan uji Tukey menunjukan jumlah spermatozoa dan prosentase viabilitas spermatozoa pada kontrol normal tidak berbeda bermakna dengan 
kontrol negatif akan tetapi terdapat perbedaan yang signifikan dengan kelompok perlakuan. Semakin tinggi dosis ekstrak semakin kecil jumlah spermatozoa dan prosentase viabilitas spermatozoa. Dan ekstrak yang memiliki nilai rata-rata jumlah spermatozoa dan prosentase viabilitas spermatozoa paling rendah adalah ekstrak etanol dengan dosis $150 \mathrm{mg} / \mathrm{kg}$ BB. Penurunan prosentase viabilitas spermatozoa hingga dibawah $40 \%$ menunjukan nilai semen yang kurang baik dan berhubungan dengan infertilitas.

Dari hasil penelitian diketahui ekstrak daun pepaya yang diberikan secara oral selama 20 hari dapat menurunkan bobot testis dan vesika seminalis serta dapat menurunkan jumlah spermatozoa dan viabilitas spermatozoa. Dari ketiga ekstrak daun pepaya yang memiliki aktivitas paling baik sebagai antifertilitas adalah ekstrak etanol. Hal ini diduga disebabkan oleh kandungan flavonoid dalam ekstrak daun pepaya yang tertarik oleh pelarut polar. Daun pepaya memiliki kandungan metabolit sekunder yaitu flavonoid yang diduga dapat menyebabkan lemahnya fungsi sperma. Flavonoid yang terkandung dalam ekstrak daun pepaya dapat menyebabkan peningkatan antioksidan dalam tubuh. Flavonoid mampu membentuk Reactive Oxygen Species (ROS) yang dapat merusak membran plasma spermatozoa (Nayanatara et al. 2008). Peningkatan kadar ROS yang melampaui batas pertahanan antioksidan tubuh akan menghasilkan stress oksidatif sehingga akan menyebabkan kerusakan sel, jaringan dan organ. Tingginya kadar ROS pada sperma dapat mengakibatkan 40,88 \% pasien pria mengalami infertilitas (Sikka 2004). Stress oksidatif juga akan menurunkan aktivitas hormon steroid yang berperan untuk proses spermatogenesis (Maneesh et al. 2005). Kerusakan membran plasma pada spermatozoa dapat menyebabkan pompa natrium tidak lagi berfungsi dengan baik untuk mengatur sirkulasi zat-zat dari dan keluar sel sehingga pewarna Giemsa masuk ke dalam sel dan tetap tinggal di dalam dan mewarnai spermatozoa menjadi biru terutama pada bagian kepala. Spermatozoa yang hidup memiliki membran plasma yang masih utuh sehingga pompa natrium dapat berfungsi dengan baik (Delfita 2014).

\section{SIMPULAN}

Pemberian ekstrak daun pepaya selama 20 hari pada tikus putih jantan galur Sprague Dawley dapat menurunkan jumlah spermatozoa dan viabilitas spermatozoa serta dapat menurunkan bobot testis dan vesika seminalis. Ekstrak daun pepaya yang paling baik dalam menurunkan jumlah spermatozoa, viabilitas spermatozoa, bobot testis, dan vesikula seminalis adalah ekstrak etanol dengan dosis $150 \mathrm{mg} / \mathrm{kg} \mathrm{BB}$.

\section{DAFTAR PUSTAKA}

Adnan dan H. Pagarra. 2000. Pengaruh Ekstrak Rimpang Tumbuhan Pacing (Costus speciosus J.E. Smith) terhadap Fertilitas Mencit (Mus musculus) IRC Jantan. Universitas Negeri Makasar.

Agustina D. dan H. Muwarni. 2013. Pengaruh Pemberian Jus Biji Pepaya (Carica papaya L.) Terhadap Rasio Kolesterol LDL: HDLTikus Sprague Dawley Dislipidemia. Jurnal of Nutrition College. 2 (3) : $302-311$

BKKBN. 2016. Laporan Kinerja Instansi Pemerintah Badan Kependudukan dan Keluarga Berencana Nasional 2015. https://www.bkkbn.go.id/pocontent/uploads/LAKIP_BKKBN_2016.pdf. [diunduh 2019 Juni 1)

Delfita R., 2014. Potensi Antifertilitas Ekstrak Teh Hitam Pada Mencit (Mus musculus L.) Jantan. Jurnal Sainstek. Batu Sangkar. Vol. VI (2) : 181-188.

Departemen Kesehatan Republik Indonesia (Depkes). 1995. Materi Medika Indonesia. Jilid VI. Jakarta (ID) : Departemen Kesehatan Republik Indonesia.

Departemen Kesehatan Republik Indonesia (Depkes).. 2000. Parameter Standard Umum Ekstrak Tumbuhan Obat. Jakarta. (ID) : Direktorat Jendral Pengawasan Obat dan Makanan.

Departemen Kesehatan Republik Indonesia (Depkes). 2008. Farmakope Herbal Indonesia. Edisi I. Jakarta (ID): Direktorat Jendral Pengawasan Obat dan Makanan.

Guyton A. C and J.E Hall. 2008. Buku Ajar Fisiologi Kedokteran. Edisi 11. Jakarta (ID) : Penerbit Buku Kedokteran. EGC.

Hanani E. 2014. Analisis Fitokimia. Jakarta (ID) Penerbit Buku Kedokteran. EGC.

Kementerian Perencanaan Pembangunan Nasional (Bappenas). 2019. Jumlah Penduduk Indonesia 2019 Mencapai 267 Juta Jiwa. https://databoks.katadata.co.id/datapublish/2019/0 1/04/jumlah-penduduk-indonesia-2019-mencapai267-juta-jiwa. [diunduh 2019 Juni 1)

Mahatriny NN, Payani NPS. Oka IBM. Astuti KW. 2014. Skrining Fitokimia Ekstrak Etanol Daun Pepaya (Carica papaya L.) Yang diperoleh Dari Daerah Ubud, Kabupaten Gianyar Bali. Jurnal Farmasi Udayana, Bali. 3 (1) : 8 - 13

Maneesh M, Jayalekshmi H, Dutta S, Chakrabarti A, Vasudevan D. 2005. Role of Oxidative Stress in Ethanol Induced Germ Cell Apoptosis- an

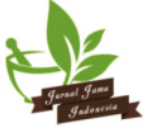


Experimental Study in Rat. Ind J Clin Biochem. 20 (2): $62-67$

Mayasari D, Mardiroharjo N. 2012. Pengaruh Pemberian Boraks Peroral Sub Akut Terhadap Terjadinya Atrofi Testis Tikus Putih Jantan (Rattus novergicus Strain Wistar). eJournal UMM. 8 (1): 22 27.

Nayanatara A, Vinodini N, Damodar G, Ahamed B, Ramaswamy C, dan Shabarinath B.R. 2008. Role of Ascorbic Acid in Monosodium Glutamate Mediated Effect on Testicular Weight, Sperm Morphology and Sperm Count, in Rat Testis. Journal of Chinese Clinical Medicine. $3: 1-5$

Nuraini T, Kusmana D, Afifah E. 2012. Penyuntikan Ekstrak Biji Carica papaya L. Varietas Cibinong pada Macaca fascicularis L. Dan Kualitas Spermatozoa Serta Kadar Hormon Testosteron. Makara Kesehatan. 16 (1) : 9-16.

Oyewopo AOA, Oremosu AE, Akang N, Noronha CC, Okanlawon AO. 2011. Effects of Aloe vera (Aloe barbadensis) Aqueous Leaf Extract on Testicular Weight, Sperm Count and Motility of Adult Male Sprague Dawley Rats. J.A.M. Sci. 7 (4) : 31-34.
Prasetyaningrum N, Muslichah S, Hidayat A M. 2015. Pengaruh Ekstrak Metanol, Fraksi N-Heksan dan Fraksi Metanol Biji Pepaya (Carica papaya L.) terhadap Motilitas Spermatozoa Tikus. [Skripsi] Jember (ID) : Universitas Jember.

Priyatno D. 2012. Belajar Praktis Parametrik Dan Non Parametrik Dengan SPSS. Yogyakarta (ID) : Gaya Media.

Rahayu S, Tjitraresmi A. 2016. Tanaman Pepaya (Carica papaya L.) Dan Manfaat Dalam Pengobatan. Farmaka. 14 (1) : 2-10.

Rudini M. 2016. Efektivitas Antidiabetes Ekstrak Etanol Rimpang Pacing (Costus speciosus) dan Taurin Terhadap Fertilitas Mencit Jantan (Mus musculus) yang Diinduksi Aloksan. [Tesis]. Bandar Lampung (ID) : Universitas Lampung.

Sikka S C. 2004. Relative Impact of Oxidative Stress on Male Reproductive Function. Curr Med Chem. 8 : 851-862.

Simbolon, IS. TM. Lubis. T. M. Adam. 2013. Persentase Spermatozoa Hidup pada Tikus Wistar dan Sprague Dawley. Jurnal Medika Veterina. 7 (2) : 79 - 83

Sutinah. 2017. Partisipasi Laki-laki Dalam Program Keluarga Berencana di Era Masyarakat Postmodern. Masyarakat, Kebudayaan dan Politik. 30 (3) : 289299

Tasmaya R. 2000. Menuju Paradigma Baru Keluarga Berencana. Warta Demografi. 30 : 33-45. 